\title{
THE EFFECT OF INTERNAL GOVERNANCE ON CORPORATE FINANCIAL CRIME OF COMPANIES IN MALAYSIA
}

\author{
Wan Nailah Abdullah', Roshima Said1, ${ }^{*}$, and Kiymet Caliyurt² \\ ${ }^{1}$ Faculty of Accountancy, Universiti Teknologi Mara, Malaysia \\ 2 Faculty of Business Administration and Economics, Trakya University, Edirne, Turkey
}

ABSTRACT - This empirical study proposes to examine one of the main areas in corporate governance i.e., the internal governance factors and their relationship with corporate financial crime and to find out whether their effectiveness as a corporate governance mechanism is still relevant in the prevention of corporate financial crime. The internal governance factors tested in the study are audit diligence, audit size, employee shares option scheme, managerial ownership and standalone risk management committee. The research was carried out by using a web-based data collection for corporate financial crime cases. The findings indicate a significant relationship between the existences of a stand-alone risk committee with corporate financial crime incidences. The result of the study serves as an empirical indicator for a firm's consideration in deciding on the implementation of a stand-alone risk committee from its audit committee. Both the descriptive and correlation analyses produced by this paper provide new insights into the extent of corporate financial crime, as well as the empirical evidence of the effectiveness of having a stand-alone risk committee.

\author{
ARTICLE HISTORY \\ Received: 08-04-2019 \\ Accepted: 19-06-2019

\section{KEYWORDS} \\ Financial Crime, Internal \\ governance, Audit Committee, \\ Risk Committee, Ownership
} Structure

\section{INTRODUCTION}

Corporate financial crimes, such as money laundering, insider trading, financial statement fraud, theft, and bribery, are either committed by individuals who are the officials in the organisations for their own personal motives or for the sake of the organisations have been ubiquitous in the global market. Hence, today, corporate financial crime has been receiving massive attention that has led to an intense public demand for higher standards of ethical and governance practices by private and public organisations throughout the whole world. This phenomenon is understandable due to the costly impact of such corporate financial crimes that can severely harm the economy of the global market (Atbani, 2007). For such reasons, efforts to prevent, stop or at least hinder corporate financial crime have been intensified at various national, regional as well as international levels around the globe.

Corporate financial crime can be very difficult to detect. It is motivated by many different factors and achieved in many ways. The Fraud Investigation \& Dispute Services (Ernst \& Young, 2016) who conducted interviews and listened to over 500 corporate leaders including chief executive officers, chief finance officers, chief risk officers, internal audit directors, and business unit directors has revealed the following findings: first, internal controls are still the most likely factor to prevent and detect fraud; second, nearly 90 per cent of the respondents believed controls were sufficient within their organisation to identify and investigate fraud promptly; and third, 50 per cent of the respondents investigated the fraud with the desire to identify and improve control weaknesses, hence preventing future acts of fraud.

The accounting scandals occurring at prominent companies, such as Enron, HealthSouth, Tyco, WorldCom, seem to indicate the flaws in corporate governance, the accounting profession, and regulatory bodies, and as a result, has shaken the confidence of the investors. Many of these companies have been forced to file for bankruptcy. From the initial observations of the study, in Malaysia, most corporate financial crimes involving public listed companies are pertaining to fraud and falsifications of the financial statements. Thus, there has been much attention given by the authorities to this type of corporate financial crime. Several companies in the Malaysian market have been publicly reprimanded by the Securities Commission and directed to rectify and reissue financial statements. These companies, amongst others include NasionCom Holding Berhad, MEM Technology Berhad, Oilcorp Berhad, and Talam Corporation Berhad. For example, NasionCom Holding Berhad's (NHB) revenue of RM194,984,186 as reflected in its 2005 financial statements which were made up by a total of RM143,109,727 sales were not actually transacted. These sales were falsely recorded in the financial statements of two NHB's subsidiaries; Nasioncom Sdn. Bhd. and Express Top-up Sdn Bhd. NasionCom Holding Berhad was required to rectify and reissue its financial statements for the financial year ended 31 December 2005 (Securities Commission, 15 February, 2007).

With various measures taken to deter these crimes at various levels, the crimes just have not seemed to reach their ending toll. Corporate governance mechanisms have been practically utilised in many countries as the effective tools in restraining many corporate misbehaviour problems. Corporate governance mechanisms are specially implemented in 
public traded companies where it involves large amount of public's interests, including shareholders' and stakeholders'. Therefore, the study proposes to examine one of the main areas in corporate governance i.e., the internal governance factors and their relationship with corporate financial crime to find out whether their effectiveness as a corporate governance mechanism is still relevant in the prevention of corporate financial crime.

\section{LITERATURE REVIEW}

\section{Corporate Governance and Corporate Financial Crime}

There have been several attempts to associate the existence of corporate financial crime to corporate governance. Given the wide array of acts covered in the term corporate financial crime, previous researchers have tried to link corporate governance to a narrower concept of crime, most of them pertaining to earnings management or financial statement/reporting fraud, for instance, Beasley (1996), Klein (2002), Burns and Kedia (2006), and Mitani (2010). Beasley (1996) found that financial statement fraud is more likely to occur in firms with insider-dominated boards. Klein (2002) showed that an increase in the number of insiders on boards or Audit Committees is associated with greater earnings management. Burns and Kedia (2006) showed a positive relation between the performance-based managerial incentive scheme and earnings management. Abdul Rahman, Muhamad and Othman (2006) found earnings management had a positive relationship with the size of the board in Malaysia. Ho (2009), who studied the association between board characteristics and accounting conservatism in Malaysia, found evidence of a negative relationship between the percentage of inside directors and conservatism, and board size and conservatism.

Many studies mentioned above have been done on narrower areas of corporate financial crime in the sense that, earnings management and fraud are only two of the 14 sub-areas of corporate financial crime. For example, Halbouni, Obeid and Garbou, (2016), Hasnan, Rahman and Mahenthiran, (2014) and; Ismail and Abdelmoniem (2013) are some of the recent studies done on the area of corporate governance and its effects on fraud, when fraud is only one part of corporate financial crime (Gottschalk, 2010b) used in the current study.

\section{Internal Governance as Controlling Mechanism}

Denis and McConnell (2003) and; Mitani (2010) argued that corporate governance can be broadly classified into internal governance and external governance mechanisms. Internal governance mechanisms are those related to managerial ownership, ownership concentration, and executive compensation or stock options. The purpose of the current study is to analyse the relationship between some of these corporate governance mechanisms and corporate financial crime incidences, by suggesting that corporate financial crime incidences will be affected through the implementations of good internal governance mechanisms.

Previous studies investigated internal and external governance in relation to various areas. One of the areas was the association between the levels of internal and external corporate governance characteristics and internal control quality. Boubacar (2018) investigated the effect of internal governance characteristics towards the financial and social performance of Niger's MFIs. Two mechanisms used by Boubacar (2018) as internal governance mechanisms, i.e., CEO/Chairman role duality and board size. Krishnan (2005) and; Bedard, Johnstone and Smith (2010) reported a positive association between the levels of high quality internal corporate governance (audit committee expertise and independence) and internal control quality. Zhang, Zhou, and Zhou (2007) found that both levels of internal governance (audit committee financial expertise) positively associated with internal control quality. In contrast, Jensen and Payne (2003) found that the levels of internal governance (existence of internal audit function and accounting staff expertise) and external governance (external auditor industry experience) are substitutes for one another in the monitoring of internal control systems.

\section{Hypotheses Development}

\section{Managerial and Employees Stock Ownership}

The traditional agency literature presents that shareholdings by managers help to align their interests with those of shareholders (Jensen \& Meckling, 1976). This alignment effect suggests that corporate financial crime as a proxy for opportunistic behaviours decreases uniformly with an increase in managerial stock ownership. That is, managerial shareholdings are good for the corporate governance. There is a growing consensus that the stock holdings of directors should be increased (McKendall, Sánchez \& Sicilian, 1999). It is assumed that if directors have enough personal financial wealth at stake, directors will begin to think more similarly to stockholders and attach greater importance to company performance (Monks \& Minow, 1995).

On the other hand, whilst stock ownership could prompt directors to take a greater interest in the firm, it can be argued that a high degree of financial involvement in the firm by directors and top management teams might compromise their ability to objectively evaluate and control firm choices (McKendall, et al., 1999). Significant stock ownership might encourage directors to act more in the short-term financial interests of shareholders and less in the external and/or longterm interests of other stakeholders. The more the personal fortunes of directors are dependent on the financial performance of the firm, the more important financial performance becomes relative to other competing outcomes. Maran and Indraah (2009) pointed that a chief executive officer's stock ownership can lead to a convergence of interests between managers and shareholders. Consequently, it can be expected that as management ownership increases, the incentives to commit financial crime will decrease. However, to the extent that managers' and shareholders' interests are not fully aligned, higher stock ownership can give managers much power to pursue their own objectives without fear of punishment 
that is, it can entrench managers (Fama \& Jensen 1983). The chief executive officer's stock ownership, instead of reducing managerial incentive problems, may entrench the incumbent management teams, leading to increasing managerial opportunism (Fama \& Jensen 1983; Maran \& Indraah, 2009). It was also been found that firms with higher managerial ownership are associated with more earnings management (Mitani, 2010). The current study proposes that when directors and top management teams have sufficiently higher stock ownership, they will be more inclined towards corporate financial crime activities.

Another mechanism through which shareholders can induce managers to behave efficiently is incentive contracts which use managers' compensations in measuring corporate performance. This can be accomplished through performance related bonuses, stock grants and stock options. However, executive incentives pay has been criticized as being manipulated or controlled by the executive themselves. The conflict of interests between the shareholders and the chief executive officers represent a classic example of principal-agency problem (Jensen \& Murphy, 1990).

The agency theory predicts that compensation policy will be designed to give managers incentives to select and implement actions that will increase shareholders wealth. The problem in the corporate governance is the conflict of interest between firms' dispersed owner-investors and the managers hired to determine firms' investment projects and pay out decisions. Grant of stock options is motivated by a desire to align managers' incentives with those of shareholders. However, stock option may have the perverse effect of encouraging managers to exploit their discretion in reporting earnings in order to manipulate the stock prices of their companies.

The recent empirical evidence supports such inefficient function of the stock option. Directors' shareholdings were found to be significantly associated with corporate performance in a negative direction (Chiang, 2005) while excessive insider ownership by managers has resulted in even worse corporate performance (Han \& Suk, 1998). Companies with high and low levels of managerial ownership were found to be engaging in more earnings management compared to companies with intermediate levels of managerial ownership (O'Callaghan, Ashton \& Hodgkinson, 2018).

Evidences from prior researches have also shown that managers tend to waste free cash flows in their organisations where good governance is not in place (Demsetz \& Lehn, 1985; Dittmar \& Mahrt-Smith, 2007), and thus will eventually lowering the companies' values. In the absence of high and good internal governance, the conflicts of interests between managers and minority shareholders are argued to be leading into managers gaining higher discretion into cash hoarding (Kusnadi, 2011) and thus increasing the propensity for corporate financial crime incidences. There are also evidences on the positive relation between executive stock option and corporate financial crime (Bergstresser \& Philippon, 2006; Burns $\&$ Kedia, 2006). Manager's opportunity to disguise true economic performance through discretionary accruals in private firms will be related to managerial ownership (O'Callaghan, et al., 2018). Thus, it is postulated in the current study that stock ownership by managers and employees will expose the companies in corporate financial malfeasance. Therefore the hypotheses are:

Hypothesis 1: There is a significant positive relationship between managerial ownership and corporate financial crime incidences.

Hypothesis 2: There is a significant positive relationship between the existence of employee stock option scheme and corporate financial crime incidences.

\section{Audit Committee}

The emergence of corporate governance as a controlling mechanism in the global market has led to the audit committee gaining much attention and significant clout in the internal control. As having an audit committee is normal practice by most organisations, in Malaysia the establishment of an independent audit committee has been mandatory since the earlier years of corporate governance implementation. This compulsory requirement was imposed by Bursa Malaysia on its listed companies as part of its efforts in promoting the best standard of corporate governance. Despite the audit committee being associated with part of the best corporate governance practices, the effectiveness of the committee in hindering corporate financial crime is questionable based on the escalating cases each year in the country. It is crucially important to examine the audit committee characteristics as well as their relationship and influence so as to determine their effectiveness as a corporate governance mechanism. This would be needed by the legislators, government officials, public investors as well as the researchers to trace whether the audit committee's role as a governance mechanism is still relevant. Previous studies have explored the effectiveness of the audit committee to prevent such corporate misbehaviour to uncover accounting fraud or irregularities in large firms within a short-term period of time. The study by Beasley, Carcello, Hermanson and Lapides (2000) suggested six main areas which may prevent criminal activities from taking place, of which, one of them is through the existence of an effective audit committee. The audit committee has been said to be the key tool for preventing corporate financial crime and ensuring that the management of financial matters is run with the highest integrity. Therefore, it is crucially important that audit committee members fully exercise their duties.

One of the indicators for accessing whether the audit committee members are really performing their duties is through the number of meetings held and attended. Audit committees which meet at least every six months are associated with less misbehaviour by the firm (Abbott, Parker \& Peters, 2004). Is important that audit committee to spend sufficient time in usual meetings in order to uncover possible corporate financial crime issues (Musallam 2018). Frequent audit committee meeting allows audit committee to be continuously informed regarding relevant accounting and auditing issues, allows its directors with more opportunity in discussing and evaluating issues (Musallam, 2019). 
Besides the audit committee meeting frequency, the other important characteristic of the audit committee is the number of audit committee members. As the duties of the audit committee, amongst others, include communicating problems and findings with managers and both internal and external auditors in time, thus having sufficient members is seen as important so as to ensure all tasks or jobs may be performed as scheduled. Audit committee size was found to be significantly associated with financial reporting quality in positive direction (Appuhami \& Tashakor, 2017). Not only audit committees with more members can provide sufficient knowledge base, it also can mitigate the influence imposed by managers because large audit committees are more likely to have members with varied expertise (Sun, Lan \& Liu, 2014). This varied expertise will ensure audit committee members to monitor financial reporting practices more effectively. (Sun, et al., 2014) and thus may be able to prevent corporate financial crime.

Diligence has become one of the key qualities attributed to the audit committee. The audit committee has now become so significant that their power in the financial reporting process has increased (Harrast \& Olsen, 2007), thus indicating the increasing importance of the audit committee's function as the governance mechanism in exercising control for the purpose of hindering an organisation's misleading behaviour, such as corporate financial crime. Audit committee meetings have been associated with the larger size of a company or in a company which is in litigious industries (Raghunandan \& Rama, 2007).

Hypothesis 3: Audit meeting's frequency is negatively associated with corporate financial crime.

Hypothesis 4: Audit member's size is negatively associated with corporate financial crime.

\section{Risk Committee}

Corporate Governance has been established and practiced widely by almost all countries in the world for best practices as well as to prevent criminal activities. Principle six of the Malaysian Code of Corporate Governance (MCCG) recommends that the board of directors is to establish a risk management framework and internal control system. The board should thus provide a sound framework to manage risks. The MCCG also suggests that the board should manage risk by determining risk tolerance as well as assessing and monitoring business risks in the risk committee. It has been a normal practice by most organisations that an audit committee's duties would include the oversight function of the company's risk management strategic tasks. The research question is whether a risk committee should be implemented as an independent committee, separated from the functions of the audit committee in the efforts of hindering the incidences of corporate financial crime.

Traditionally, the risk management functions are managed by and under the responsibility of the audit committee. Malaysia has been like other countries in that, the risk management functions in the companies are being dumped into the responsibility of the audit committee which has many other crucial areas of tasks to be looked into. Whilst the audit committee is being burdened by the risk management's supposed functions, the latter's scope of areas to be attended to is now being narrowed down to a level that can be managed by the limited ability of the former alone. As the range of risks associated with the business' operation is wide, composing both financial and non-financial risks that can pass beyond the audit committee's scope. As such, it has been argued that a separate risk committee must now be established to deal with the specific risk management matters away from the responsibilities of the audit committee ( $\mathrm{Ng}$, Chong \& Ismail, 2012). Nevertheless, in doing so, careful measurements should be taken into consideration before a decision is made into establishing a separate risk committee because the creation of such a risk committee can itself create risks (Eggleston \& Ware, 2009). This is crucial as the board member who delegates the monitoring of the risk tasks to the new committee must stay focused because managing risks is the core function of the board itself (Eggleston \& Ware, 2009). In addition it will also create confusion as some of the risk tasks are left with the audit committee, thus uncertainty arises and there are overlapping effects of the risk management efforts (Eggleston \& Ware, 2009) by both or more interrelated parties. Despite these possible risky consequences, it has been suggested that the establishment of a risk committee will promote adequate industry health and strength, or at least the effective risk committee should assist organisations in achieving their objectives and secure the organisational reputation as well as provide improved quality financial reporting (Ng, et al., 2012; Subramaniam, McManus \& Zhang, 2009). A lack of consensus on whether a company should practice a combined risk committee function in its audit committee or a stand-alone risk committee which is separated from the audit committee has led the study into raising this matter to be considered as part of good governance strategies (Abdullah \& Said, 2019). Good governance strategies i.e., should a company be required to have a stand-alone audit committee which is responsible with the oversight of the company's risk management strategy, or a stand-alone audit committee and stand-alone risk committee, or a combined audit and risk committee (Abdullah \& Said, 2019). The study contends that, as their risk assessment tasks become more focused resulting from being free from the audit committee functions, a standalone risk committee could yield more effective risk management that would be able to prevent corporate financial crime.

Hypothesis 5: A stand-alone risk committee is negatively associated with corporate financial crime.

\section{RESEARCH METHODOLOGY}

This is a correlational study that is based on secondary data collected from various available sources, like the criminal cases reported in the Securities Commission of Malaysia, law journals, annual reports, and proxies, as well as in news reports available on the internet. The study has used the purposive sampling technique where all the companies in the population were taken as the sample (Lewis \& Sheppard, 2006). The data for dependent variable, namely corporate financial crime are represented by corporate financial crime incidence cases throughout the years from 2002 until 2015. 
The reason for choosing this period of time was to capture the period where corporate governance best practice was implemented in Bursa Malaysia. The examined annual reports were for the year before the announcement of the corporate financial crime incidences in order to avoid capturing any changes taking place to the company's governance structure after the discovery of the crime; this was to ensure that the data reflected the position of the firm whilst the crime was still on-going. Therefore, for this period of corporate financial crime cases, the annual reports that were chosen as the sample included those in 2001 until 2014.

The dependent variable in this study is corporate financial crime. Corporate financial crime can be defined as "...any non-violent crimes against property to earn wealth illegally, involving the unlawful conversion of property (belonging to the company or a third party) by the officials in the organisations for personal or organisational benefits that results in a financial loss to the victims".

The study used five independent variables which correlated with corporate financial crime: (i) Managerial stock ownership (percentage of stock owned by managers), (ii) Employee Stock Option Scheme (ESOS) (existence of ESOS in the company), (iii) Audit Committee Diligence (number of audit committee meetings in the year, (iv) Audit Committee Size (number of audit committee members), and (v) Stand-alone Risk Committee (existence of a stand-alone risk committee). Data analysis was performed using the IBM Statistical Package for Social Science (SPSS) Version 20. The dependent variable in the study was categorical where the only possible values were 'yes' or 'no' ("yes" coded as " 1 " for companies in which there were corporate financial crime incidences and "no" coded as " 0 " for companies that were free from corporate financial crime). The Logistic Regression was suitably applied in order to produce the required results. Table 1 provides summary for the measurement of the independent variables.

Table 1: Measurement of independent variables

\begin{tabular}{ll}
\hline \multicolumn{1}{c}{ Variables } & Measurement \\
\hline \hline Managerial Ownership (MgrO) & The percentage of shares owned by Managers and Top \\
& Management teams. \\
The existence of an Employee Share Option & $0=$ no for companies not having an employee option scheme, \\
Scheme (Esos) & $1=$ yes for companies having an employee stock option scheme. \\
Audit Committee Diligence (AudDil) & Number of audit committee meetings held in the year. \\
Audit Committee Size (AudSize) & Number of audit committee members. \\
The existence of a Risk Management & $0=$ no for non-existence of a risk committee in the companies, \\
Committee (RiskCom) & $1=$ yes for the existence of a separate risk committee from the audit \\
\end{tabular}

\section{FINDINGS AND DISCUSSION}

The results of the matching process are presented in Table 2. Table 2 provides frequency details of the spread of corporate financial crime occurrences over times, standard industry code matching, financial crime distribution by industry and characteristics of company size. 
Table 2: Matching Criteria Frequency

PANEL A: OCCURRENCE OF CRIME CASES (Source: Securities Commission of Malaysia)

\begin{tabular}{|c|c|c|c|c|c|c|c|c|c|c|c|c|c|c|}
\hline & 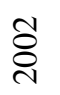 & ্ֻণ & 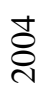 & ஜ & ঠ্ণ & હ্ণ & $\stackrel{\infty}{\stackrel{\infty}{ٍ ~}}$ & ஓి & 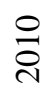 & $\overline{\bar{D}}$ & $\frac{\sim}{\stackrel{\sim}{d}}$ & 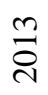 & 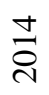 & $\stackrel{n}{\circ}$ \\
\hline Total Crime & & & & & & & & & & & & & & \\
\hline Cases $=41$ & 7 & 5 & 7 & 3 & 6 & 4 & 5 & 2 & 1 & 1 & 0 & 0 & 0 & 0 \\
\hline $\begin{array}{l}\text { Total } \\
\text { Matched } \\
\text { Pair }\end{array}$ & & & & & & & & & & & & & & \\
\hline $\begin{array}{l}\text { Companies } \\
\text { without } \\
\text { Crime Cases } \\
=82\end{array}$ & 14 & 10 & 14 & 6 & 12 & 8 & 10 & 4 & 2 & 2 & 0 & 0 & 0 & 0 \\
\hline
\end{tabular}

PANEL B: DISTRIBUTION OF CRIME AMONG INDUSTRY TYPE

\begin{tabular}{|c|c|c|c|c|c|c|}
\hline $\begin{array}{l}\text { Name of } \\
\text { Industry }\end{array}$ & $\begin{array}{c}\text { Industrial } \\
\text { Product (IP) }\end{array}$ & $\begin{array}{l}\text { Property } \\
\text { (PP) }\end{array}$ & $\begin{array}{l}\text { Trading\& } \\
\text { Services } \\
\text { (TS) }\end{array}$ & $\begin{array}{c}\text { Consumer } \\
\text { Product (CP) }\end{array}$ & $\begin{array}{c}\text { Constructio } \\
\text { n } \\
\text { (C) }\end{array}$ & TOTAL \\
\hline Frequency & 14 & 7 & 8 & 10 & 2 & 41 \\
\hline Percentage & $34 \%$ & $17 \%$ & $20 \%$ & $24 \%$ & $5 \%$ & $100 \%$ \\
\hline \multicolumn{7}{|c|}{ PANEL C: DESCRIPTIVE STATISTIC FOR SIZE } \\
\hline & $\mathrm{N}$ & Minimum & Maximum & Mean & $\begin{array}{c}\text { Std. } \\
\text { Deviation }\end{array}$ & \\
\hline Size & 123 & $7,523,000.00$ & $\begin{array}{c}8,673,240,8 \\
51.00\end{array}$ & $\begin{array}{c}667,532,609.0 \\
4\end{array}$ & $\begin{array}{c}1,835,997,0 \\
84.26\end{array}$ & Size \\
\hline $\begin{array}{c}\text { Valid N } \\
\text { (listwise) }\end{array}$ & 123 & & & & & $\begin{array}{c}\text { Valid N } \\
\text { (listwise) }\end{array}$ \\
\hline
\end{tabular}

All pairs of companies were matched based on three criteria: the time, the standard industry code and the total assets as a proxy for size of company. First, the matching for time criteria required the information used in the matching process to be based on the financial data recorded for each company in the year prior to the incidence of corporate financial crime. For instance, in Company A where the case of corporate financial crime reported to be committed in the year 2011, the data extracted would be from the Company A's annual report of 2010. This method allows data to be collected in the year prior to the crime incidence because according to Hasnan, et al., (2014), there were much intervention and alteration of the financial statements carried out during the year of the crime. Therefore, by capturing data before the year of the crime, the data will be more accurate in the sense that it represents the real situation of the companies' business condition, before any alteration or manipulation done for the purpose of crime, if any.

Panel A of Table 2 shows the year distribution of the financial crime occurrences and reveals that just almost 80 per cent of the corporate financial crime occurred within the six years period between year 2002 to 2007, with the 20 per cent balance of the corporate financial crime cases occurred in the rest of six most recent years, that is, from 2008 until 2014. This pattern of corporate financial crime cases occurrence which concentrates on the earlier years of the research range can be inferred as the results of the "learning stage" of the newly implemented Malaysian Code of Corporate Governance which was initiated in 2001. As the years passed by, the corporate governance standards could have, even though not in total effectiveness, slowly shown to be playing its role in the corporate financial crime prevention. The crime has appeared to be lesser in number and in its frequency of occurrences in the later years, especially in the three most recent years of the study, 2012, 2013, 2014, and 2015 where the record of the corporate financial crime incidences reported to be zero in cases. Panel A also indicates that each of the corporate financial crime case is paired with two non-crime cases. Meaning that, for example Company A, in which corporate financial crime incidence has reportedly been occurred, was matched with two companies of the same size, industry type in the same time frame, but which no corporate financial crime incidence occurred in them.

Panel B of Table 2 indicates the frequency of corporate financial crime incidence occurrence by industry type, indicating the highest number of companies (14 companies or 34 per cent) which committed corporate financial crime came from the industrial product companies. The next highest-ranking industry is the consumer product which accounted for 24 per cent (10 companies) of the cases, followed by the rest of the remaining industries where the occurrence of 
corporate financial crime incidences were fairly evenly spread out amongst them; with trading and services ( 8 companies or 20 per cent) and property ( 7 companies or 17 per cent). Construction industry apparently came out as the least (2 companies or 5 per cent) occurrence of corporate financial crime cases of all the samples.

The industrial product sector apparently carries the highest risk for corporate financial crime incidences. The high number of corporate financial crime incidences occurring in this industry usually due to the nature of this industry which makes it susceptible to, for example, noncash frauds, including the stealing of goods and materials by employees, as well as intellectual property. In the scope of the current study, industrial products sector is found to be prone to fraud. The types of fraud in this sector could be in the form of insider trading, trade secrets and billing frauds, due to the variety of products produced in the assembly. In addition, the expense reimbursement fraud is also common in industrial product sector due to the sales forces employed by the industrial products companies.

Panel C of Table 2 indicates the descriptive statistics for the matching criteria variables of size. Out of the total 123 companies in the sample, the minimum size of total assets is RM7.5 million, the maximum size is RM8.6 billion while the mean size is RM667.5 million and standard deviation is RM1.8 billion. The results indicate that the least total assets belong to the companies in the sample is amounted to RM7.5 million while the most total assets of the companies in the sample is amounted to RM8.6 billion, indicating an average total assets of the whole companies in the sample amounting to RM667 million.

The standard deviation or variance of the total assets belonging to the companies is recorded at RM1.8 billion. The huge amount of standard deviation is acceptable in the Logistic Regression because unlike in the Multiple Regression technique, the Logistic Regression does not require the error term to be normally distributed. The Logistic Regression's assumptions do not provide as many key assumptions compared to the linear regression and general linear models which are based on ordinary least squares algorithms; especially on linearity, normality, homoscedasticity, and measurement level. The assumptions of the Logistic Regression particularly do not require an existence of a linear relationship between dependent and independent variables. In addition, the error terms also are not required to be normally distributed. The Logistics Regressions assumptions also have no requirements for homoscedasticity. Based on these assumptions, obviously there is no problem associated with the huge standard deviations produced from the Logistics Regressions. Therefore the standard deviation of Size is acceptable in the study.

The types of crime indicated in Table 2 were used as the searching criteria to look for corporate financial crime cases. When the corporate financial crime cases were identified, the study were able to identify the company that involved in these crime as well and thus providing sample of the study. It is not the intention of the current study to focus deeply into one type of corporate financial crime because the study perceives corporate financial crime as the "illegal acts" committed by the organisations or individuals in the organisations that will lead to financial loss to the victims. Therefore, as long as the corporate financial crimes are being committed in the organisation, it indicates the weaknesses of the corporate governance as a control mechanism designed especially to prevent such misbehaviour from taking place. So long as there are weaknesses that can be exploited for gain, companies, other organisations, as well as private individuals will take advantage of illegal opportunities as well as be taken advantage of (Gottschalk, 2010b). In general, it is found in the study that 90 per cent of the corporate financial crime cases in the Bursa Malaysia are made up of financial statement fraud, whereas 10 per cent are due to insider trading, and other frauds like market manipulation and short selling.

Table 3: Variable Names, Labels, and Constructs

\begin{tabular}{|c|c|c|}
\hline Name & Label & Construct \\
\hline \multicolumn{3}{|c|}{ Dependent Variable } \\
\hline Crimestatus & Crime status of the companies in the sample & $\begin{array}{l}\text { Corporate financial } \\
\text { crime incidences }\end{array}$ \\
\hline \multicolumn{3}{|c|}{ Independent Variables - Continuous Variables } \\
\hline AudDil & Number of audit meetings held in the year & Internal Governance \\
\hline AudSize & Number of audit committee members & Internal Governance \\
\hline Esos & Existence of employee shares option scheme & Internal Governance \\
\hline $\mathrm{MgrO}$ & Percentage of managerial ownership & Internal Governance \\
\hline \multicolumn{3}{|c|}{ Independent Variables - Dichotomous Variables } \\
\hline RiskCom & Existence of a separate risk committee & Internal Governance \\
\hline \multicolumn{3}{|c|}{ Control Variables } \\
\hline IndType & $\begin{array}{l}\text { Type of industry as accordance to SIC listed by } \\
\text { Bursa Malaysia }\end{array}$ & Dichotomous \\
\hline Size & Size of company with total assets as a proxy & Continuous \\
\hline
\end{tabular}


Table 3 provides the descriptions of the variable names, their labels and the constructs in which they are referred to.

Table 4: Descriptive Statistics: Comparison of the means for the continuous variables of crime and non-crime companies

\begin{tabular}{lllcccc}
\hline & Crime Status & N & Mean & $\begin{array}{c}\text { Mean } \\
\text { Difference }\end{array}$ & Std. Deviation & $\begin{array}{c}\text { Std. Error } \\
\text { Mean }\end{array}$ \\
\hline \hline \multirow{2}{*}{ AudDil } & Crime & 41 & 4.660 & .280 & 1.087 & .170 \\
& Noncrime & 82 & 4.940 & & 1.391 & .154 \\
\multirow{2}{*}{ AudSize } & Crime & 41 & 3.320 & .146 & .610 & .095 \\
& Noncrime & 82 & 3.460 & & .688 & .076 \\
\multirow{2}{*}{ Esos } & Crime & 41 & .440 & .146 & .502 & .078 \\
& Noncrime & 82 & .590 & & .496 & .055 \\
\multirow{2}{*}{ MgrO } & Crime & 41 & 6.460 & 1.781 & 8.653 & 1.351 \\
& Noncrime & 82 & 8.241 & & 8.293 & .916 \\
\hline
\end{tabular}

Significance Levels: $* * *<01, * *<05, *<1$ using a one-tailed t-test assuming unequal variances.

Legend:

AudDil represents the number of Audit Meetings held in the year

AudSize represents the number of Audit Committee members

Esos represents the existence of Employee Shares Option Scheme

$\mathrm{MgrO}$ represents the percentage of managerial ownership

Table 4 provides descriptive statistics for continuous variables and comparisons of means for the crime and non-crime samples. All the variables indicate no significant difference in mean between crime and non-crime companies. These variables are Audit Diligence (AudDil) with mean difference $=.280$, Audit Size (AudSize) with mean difference of .146, Employee Share Option Scheme (Esos) with mean difference of .146 and Managerial Ownership (MgrO) with mean difference of 1.781. These variables also indicate lower means in crime companies compared to non-crime companies.

Table 5: Descriptive Statistics: Crosstab of Dichotomous Variables

\begin{tabular}{|c|c|c|c|c|c|c|c|}
\hline & & \multirow[b]{2}{*}{ Noncrime } & \multirow[b]{2}{*}{$\%$} & \multicolumn{2}{|c|}{ Crime Status } & \multicolumn{2}{|c|}{ Total } \\
\hline & & & & Crime & $\%$ & & $\%$ \\
\hline \multirow{3}{*}{ Esos*Crimestatus } & No & 34 & 41 & 23 & 56 & 57 & 46 \\
\hline & Yes & 48 & 59 & 18 & 44 & 66 & 54 \\
\hline & Total & 82 & 100 & 41 & 100 & 123 & 100 \\
\hline \multirow{3}{*}{ RiskCom*Crimestatus } & No & 34 & 41 & 35 & 85 & 69 & 56 \\
\hline & Yes & 48 & 59 & 6 & 15 & 54 & 44 \\
\hline & Total & 82 & 100 & 41 & 100 & 123 & 100 \\
\hline \multirow{7}{*}{ IndType*Crimestatus } & Industrial Product & 28 & 34 & 14 & 34 & 42 & 34 \\
\hline & Property & 12 & 15 & 6 & 15 & 18 & 15 \\
\hline & Trading\&Services & 16 & 20 & 8 & 20 & 24 & 20 \\
\hline & Consumer Product & 20 & 24 & 10 & 24 & 30 & 24 \\
\hline & Construction & 4 & 5 & 2 & 5 & 6 & 5 \\
\hline & Technology & 2 & 2 & 1 & 2 & 3 & 2 \\
\hline & Total & 82 & 100 & 41 & 100 & 123 & 100 \\
\hline
\end{tabular}

Table 5 contains descriptive statistics providing crosstabs of the dichotomous variables in the study. From Table 5, it can be seen that the total observations for each and all variables are 123, consisting of 41 observations of crime companies and 82 observations of the matched / controlled non-crime companies.

Table 5 indicates that Employee Share Option Scheme (Esos) is found to be existing more in the non-crime companies (Yes $=48$ or $59 \%$, No $=34$ or $41 \%$ ) than in the crime companies (Yes $=18$ or $44 \%$, No $=23$ or $56 \%$ ). Another Internal Governance factor i.e. Risk Committee (RiskCom) is also found to be more in the non-crime companies (Yes $=48$ or $59 \%$, No $=34$ or $41 \%$ ) compared to in the crime companies (Yes $=6$ or $15 \%$, No $=35$ or $85 \%$ ). For Industry Type (IndType), Table 5 reveals the highest frequencies of corporate financial crime incidences denominated by the Industrial Product (IP) industry type, with 34\% (14 crime companies matched with 28 non-crime companies) frequencies of corporate financial crime incidences. This is followed by Consumer Product (CP) industry with $24 \%$ (10 crime companies matched with 20 non-crime companies) frequencies of corporate financial crime incidences in second place. Trading and Services (TS) industry with $20 \%$ (8 crime companies matched with 16 non-crime companies) frequencies appears in third place, while Property (P) industry with $15 \%$ (6 crime companies matched with 12 non-crime companies) and Construction (C) industry with $5 \%$ frequencies of corporate financial crime incidences ( 2 crime companies matched with 4 non-crime 
companies) appear in fourth and fifth place accordingly. Technology $(\mathrm{T})$ industry is in the sixth and last place carrying $2 \%$ of total corporate crime incidences ( 1 crime companies matched with 2 non-crime companies

\section{Independent Sample T-test}

An independent sample t-test was conducted to compare each individual independent variable with the dependent variable (corporate financial crime incidences). The independent sample t-test was used for the purpose of comparing one independent variable's mean or average value to corporate financial crime. Table 6 illustrates the independent sample ttest for each independent variable to corporate financial crime incidences. The results of the independent sample t-test reveal out of five, only one independent variable to be significant. This independent variable is Risk Committee (RiskCom) with $t=.000$ and $p=.000$. Risk Committee indicates significant value at the level of $p$ value less than .05 , whilst the mean difference indicates the same direction as what has been hypothesised.

Table 6: Independent Sample T-Test

\begin{tabular}{lcccccc}
\hline \multicolumn{1}{c}{ Variables } & T- test & P-Value & $\begin{array}{c}\text { Mean } \\
\text { Difference }\end{array}$ & $\begin{array}{c}\text { Predicted } \\
\text { Direction }\end{array}$ & Hypothesis & Conclusion \\
\hline \hline AudDil & .261 & .973 & -.280 & - & Accept $\mathrm{H}_{0}$ & Not Significant \\
AudSize & .251 & .117 & -.146 & - & Accept $\mathrm{H}_{0}$ & Not Significant \\
Esos & .127 & .632 & -.146 & + & Accept $\mathrm{H}_{0}$ & Not Significant \\
MgrO & .271 & .509 & -1.781 & + & Accept $\mathrm{H}_{0}$ & Not Significant \\
RiskCom & .000 & $.000 *$ & -.439 & - & Reject $\mathrm{H}_{0}$ & Significant \\
IndType & 1.000 & 1.000 & .000 & + & Accept $\mathrm{H}_{0}$ & Not Significant \\
Size & .999 & 1.000 & $-3 . \mathrm{E}+5$ & - & Accept $\mathrm{H}_{0}$ & Not Significant \\
\hline
\end{tabular}

* Significant at the $<.05$ level $(1$ tailed $)$

One of the Internal Corporate Governance factors namely, Risk Committee produced significant $\mathrm{p}$ value in this independent sample t-test, thus rejecting null hypothesis and supporting Hypothesis 5: There is a significant negative relationship between Risk Committee with corporate financial crime. Meaning that corporate financial crime incidences are found to be not occurring in companies where the Risk Committee exists as a separate committee than the Audit Committee. Or, in other words, when a company has a separate Risk Committee, corporate financial crime incidences do not exist.

The significance of the relationships between Risk Committee (RiskCom) variable and corporate financial crime incidences has provided supports that this variables do importantly play some crucial roles in the occurrence of corporate financial crime incidences in the Malaysia's public listed companies. Separate Risk Committee (RiskCom) of the Internal Governance mechanism does have some weight of effects in its relationships with corporate financial crime incidences in those companies. Meaning that companies in which corporate financial crime incidences do not occur have shown to be having higher value of internal corporate governance as compared to those companies in which corporate financial crime incidences do occur.

The rest of the variables indicate no significant difference in mean between crime and non-crime companies. These variables are Audit Diligence (AudDil) with mean difference $=.280$, Audit Size (AudSize) with mean difference of .146 , Employee Share Option Scheme (Esos) with mean difference of .146 and Managerial Ownership (MgrO) with mean difference of 1.781. These variables also indicate lower means in crime companies compared to non-crime companies.

One explanation for the insignificant result relationship between managerial and employee stock ownership with corporate financial crime is that it may be due to too much emphasis on the beliefs that managerial and employee ownership (percentage of shares owned by managers and the existence of an employee stock option scheme as proxies, accordingly) will discipline managers from acting in a deviant manner from maximising the organisations' and shareholders' wealth. Both crime and non-crime companies tend to have an insignificant different amount of managerial ownership as well as the employee stock option scheme. The results suggest that corporations nowadays have been using compensation as a controlling mechanism to control the acts of managers through encouraging managerial shareholdings as well as providing the employee share option scheme, to the extent that their effects as a controlling mechanism have been indifferent in both the crime and non-crime companies.

The results also provided no significant relationship between Diligence of Audit Committee and Corporate financial crime and Size of Audit Committee and corporate financial crime. As in the era of corporate governance, the audit committee has been imposed by the regulators to be compulsory for these public listed companies, therefore, all the best practices suggested in the corporate governance, such as the Malaysian Code of Corporate Governance, have been complied with by all the listed companies in order to be legitimate in the perspective of the rulers, clients, and all market players. Thus, it has become common for all companies to have standard procedures for audit committees pertaining to their characteristics, which include their members (e.g., number of members or independence of members), as well as their activities, such as audit committee meetings. When all companies apply the same standards and requirements in their audit committees, it can be expected that there will be no differences regarding them in both crime and non-crime companies which, eventually, yielded no significant results in the study. Therefore, the role of the audit committee as a corporate financial crime controlling mechanism is somehow disputable at this stage. Although the audit committee has 
been given much attention as one of the most important internal corporate governance mechanisms, its effectiveness in hindering corporate financial crime is now still questionable.

This result provided new findings in the area of audit and risk committees, that a separate risk management committee can be an effective mechanism in combatting corporate financial crime, whilst the function of the audit committee which performs both audit and risk management tasks has shown to be insignificantly effective in doing so (refer to the results for audit committee diligence and audit committee size). The result, therefore, provided evidence to support the postulation of the current study that, a separate risk management committee should be able to improve and further strengthen the risk management function of the company thus, providing more effective control and governance that will eventually mitigate or even prevent any chances for corporate financial crime from taking place in the organisations. Hence, the study provided support to the suggestion that the establishment of a risk management committee will promote adequate industry health and strength, or at least the effective risk committee should assist organisations in achieving their objectives and secure the organisational reputations as well as providing improved quality financial reporting.

\section{CONCLUSION AND IMPLICATION}

The existence of a stand-alone risk committee in a company is associated with the non-existence of corporate financial crime incidences. Risk committee is one of the effective corporate governance mechanisms in fighting corporate financial crime or corporate misbehaviour and, therefore, supports the internal governance factors to be still relevant as a controlling mechanism in the corporate governance studies. The functions of the audit committee have lacked emphasis on the measurement of its output or even the quality of its members to prevail against the existing quantity values which has proven to be yielding mere ineffectiveness and unpleasant outcomes. This result of the study provides new findings in the area of audit and risk committees as it offers empirical evidence to the literature that a separate risk management committee can be an effective mechanism in combatting corporate financial crime, while the function of the audit committee which performs both audit and risk management tasks has shown to be insignificantly effective in doing so.

The study provides evidence to support that a separate risk management committee should be able to improve and further strengthen the risk management function of the company thus providing more effective control and governance that will eventually mitigate or even prevent any chances for corporate financial crime from taking place in the organizations. The implication of the study is that it provides a base for companies in deciding to establish a separate risk committee from audit committee, as the establishment of a stand-alone risk management committee will promote adequate industry health and strength, or at least the effective risk committee should assist organisations in achieving their objectives, secure the organizational reputations and providing improved quality financial reporting.

It should also be noted here that this study is limited to only the companies where corporate financial crime did occurred, resulting in a small amount of sample for analysis. The study used purposive sampling technique to capture the crime companies which were identified through the searching process done in the Securities Commission and LexisMalaysia websites as well as all news and reports available in the internets. Therefore, it is suggested that future research would extend the sample into wider range of companies. This way the study will be more robust because the number of actual corporate financial crime taken place could plausibly be much more than what have been whistle-blown or brought into court proceedings.

\section{REFERENCES}

Caccese, J. B., Buckley, T. A., Tierney, R. T., Arbogast, K. B., Rose, W. C., Glutting, J. J., \& Kaminski, T. W. (2018). Head and neck size and neck strength predict linear and rotational acceleration during purposeful soccer heading. Sports Biomechanics, 17(4), 462-476. https://doi.org/10.1080/14763141.2017.1360385

Huang, X., Sun, J., \& Sun, J. (2018). A car-following model considering asymmetric driving behavior based on long short-term memory neural networks. Transportation Research Part C: Emerging Technologies, 95(February), $346-362$. https://doi.org/10.1016/j.trc.2018.07.022

James, S. L., Abate, D., Abate, K. H., A Abbott, L. J., Parker, S., \& Peters, G. F. (2004). Audit committee characteristics and restatements. Auditing: A Journal of Practice \& Theory, 23(1), 69-87.

Abdul Rahman, N. M., Muhamad, N. \& Othman, A.S. (2006). The Relationship between Islamic Work Ethics and Organisational Commitment: A Case Analysis, Malaysian Management Review 41(1).

Abdullah, W. N., \& Said, R. (2019). Audit and risk committee in financial crime prevention. Journal of Financial Crime, 26(1), 223234.

Appuhami, R. and Tashakor, S. (2017), "The impact of audit committee characteristics on CSR disclosure: an analysis of Australian firms'”, Australian Accounting Review, Vol. 27 No. 4, pp. 400-420.

Atbani, F. (2007). The Prevention of Financial Crime within an Islamic Legal Framework. Journal Compilation at Institute of Economic Affairs 2007. Blackwell Publishing. Oxford.

Beasley, M. S. (1996). An Empirical Analysis of the Relation between the Board of director Composition and Financial Statement Fraud. The Accounting Review, 71: 443 - 465.

Beasley, M.S., Carcello, J.V., Hermanson, D.R. \& Lapides, P.D. (2000). Fraudulent financial reporting: Consideration of industry traits and corporate governance mechanisms. Accounting Horizons, 14 (4), $441-454$.

Bedard, J. C., Johnstone, K. M., \& Smith, E. F. (2010). Audit quality indicators: A status update on possible public disclosures and 
insights from audit practice. Current Issues in Auditing, 4(1), C12-C19.

Bergstresser, D., \& Philippon, T. (2006). CEO incentives and earnings management. Journal of financial economics, 80(3), 511-529. Boubacar, H. (2018). Internal governance mechanisms and the performance of decentralized financial systems in Niger. International Journal of Social Economics, 45(4), 629- 643.

Burns, N. \& Kedia, S. (2006), “The impact of performance-based compensation on misreporting," Journal of Financial Economics, 79 , pp. 35-67.

Chiang, H.T. (2005). An empirical study of corporate governance and corporate performance. The Journal of American Academy of Business, March, 95-101.

Demsetz, H. \& Lehn, K. (1985). The structure of corporate ownership: causes and consequences. Journal of Political Economy, 93 , $1155-1177$.

Denis, D. K., \& McConnell, J. J. (2003). International corporate governance. Journal of financial and quantitative analysis, 38(01), 136.

Dittmar, A. \& Mahrt-Smith, J. (2007). Corporate governance and the value of cash holdings. Journal of Financial Economics, 83, 599634.

Eggleston, W., \& Ware, D. (2009). Does your board need a risk committee. KPMG's Audit Committee Insights, 2nd Quarter.

Ernst \& Young (2016), 9th Annual Global Fraud Survey. Retrieved May 29, 2008, from www.ey.com/global/assets.nsf/International/FIDS_-_9th_Global_Fraud_Survey_2006/\$file/EY_Fraud_Survey_June2006.pdf

Fama, E. \& Jensen, M. (1983). Separation of Ownership and Control. Journal of Lawand Economics, 26, p. 301-325.

Gottschalk, P. (2010b), Categories of financial crime, Journal of Financial Crime, 17(4), 441-58.

Halbouni, S. S., Obeid, N., \& Garbou, A. (2016). Corporate governance and information technology in fraud prevention and detection: Evidence from the UAE. Managerial Auditing Journal, 31(6/7), 589-628.

Han, K. C., \& Suk, D. Y. (1998). The effect of ownership structure on firm performance: Additional evidence. Review of Financial Economics, 7(2), 143-155.

Harrast, S. A., \& Mason-Olsen, L. (2007). Can audit committees prevent management fraud? The CPA Journal, 77(1), 24.

Hasnan, S., Rahman, R. A., \& Mahenthiran, S. (2014). Determinants of fraudulent financial reporting: Evidence from Malaysia. Jurnal Pengurusan, 42, 103-117.

Ho, J.A. (2009). Association between Board Characteristics and Accounting Conservatism: Empirical Evidence from Malaysia. Unpublished research, Auckland University of Technology (AUT).

Ismail, T. H., \& Abdelmoniem, Z. (2013). Stock option fraud prevention in Islamic country: does corporate governance matter? Journal of Financial Reporting and Accounting, 11(1), 4-28.

Jensen, K. L., \& Payne, J. L. (2003). Management trade-offs of internal control and external auditor expertise. Auditing: a Journal of practice \& theory, 22(2), 99-119.

Jensen, M.C. \& Meckling, W.H. (1976). Theory of the firm: Managerial behaviour, agency costs and ownership structure. Journal of Financial Economics, 3, $305-360$.

Jensen, M.C., \& Murphy, K.J. (1990). Performance pay and top-management incentives. Journal of political economy, 98(2), $225-264$.

Klein, A. (2002), Audit committee, board of director characteristic, and earnings management, Journal of Accounting and Economics $33,375-400$.

Krishnan, J. (2005). Audit committee quality and internal control: An empirical analysis. The accounting review, 80(2), 649-675.

Kusnadi, Y. (2011). Do corporate governance mechanisms matter for cash holdings and firm value? Pacific-Basin Finance Journal, 19(5), 554-570.

Lewis, J. L., \& Sheppard, S. R. (2006). Culture and communication: Can landscape visualization improve forest management consultation with indigenous communities? Landscape and Urban Planning, 77(3), 291-313.

Maran, M. \& Indraah, K. (2009). Demographic diversity in top level management and its implications on firm financial performance: An empirical discussion. International Journal of Business Management, 4(6), 176-188.

McKendall, M., Sánchez, C., \& Sicilian, P. (1999). Corporate governance and corporate illegality: The effects of board structure on environmental violations. The International Journal of Organizational Analysis, 7(3), 201-223.

Mitani, H. (2010). Additional Evidence on Earnings Management and Corporate Governance. Financial Research and Training Center Financial Services Agency Government of Japan.

Monks, R., \& Minow, N. (1995). Corporate governance. Maiden, MA: Blackwell.

Musallam, S. R. (2018). The direct and indirect effect of the existence of risk management on the relationship between audit committee and corporate social responsibility disclosure. Benchmarking: An International Journal, 25(9), 4125-4138.

Mustafa, S. T., \& Meier, H. H. (2006). CAP Forum on Forensic Accounting in the Post-Enron World: Audit Committees and Misappropriation of Assets: Publicly Held Companies in the United States/les comités de vérification et le détournement de biens: les sociétés ouvertes aux états-unis. Accounting Perspectives, 5(2), 307-333.

Ng, T. H., Chong, L. L., \& Ismail, H. (2012). Is the risk management committee only a procedural compliance? An insight into managing risk taking among insurance companies in Malaysia. The Journal of Risk Finance, 14(1), 71-86.

O’Callaghan, S., Ashton, J., \& Hodgkinson, L. (2018). Earnings management and managerial ownership in private firms. Journal of Applied Accounting Research, 19(4), 648-668.

Raghunandan, K., \& Rama, D. V. (2007). Determinants of audit committee diligence. Accounting Horizons, 21(3), 265-279.

Schoepfer, A. J. (2007). CEOs and the Roles They Play in Corporate Misconduct: An Examination of CEO Characteristics. PhD Thesis, University of Florida, USA.

Securities Commission of Malaysia (2007). Corporate Governance in Malaysia. Retrieved on $\quad$ January $\quad 19, \quad 2011 \quad$ from http://www.sc.com.my/sub.asp?pageid =\&menuid=905\&newsid+\&linkid=\&type

Subramaniam, N., McManus, L., \& Zhang, J. (2009). Corporate governance, firm characteristics and risk management committee formation in Australian companies. Managerial Auditing Journal, 24(4), 316-339.

Sun, J., Lan, G., \& Liu, G. (2014). Independent audit committee characteristics and real earnings management. Managerial Auditing Journal, 29(2), 153-172.

Zhang, Y., Zhou, J. \& Zhou, N. (2007). Audit Committee Quality, Auditor Independence, and Internal Control Weaknesses. Journal of Accounting and Public Policy, 26: 300-327.

bay, S. M., Abbafati, C., Abbasi, N., Abbastabar, H., Abd-Allah, F., Abdela, J., Abdelalim, A., Abdollahpour, I., Abdulkader, R. S., 
Abebe, Z., Abera, S. F., Abil, O. Z., Abraha, H. N., Abu-Raddad, L. J., Abu-Rmeileh, N. M. E., Accrombessi, M. M. K., ... Murray, C. J. L. (2018). Global, regional, and national incidence, prevalence, and years lived with disability for 354 diseases and injuries for 195 countries and territories, 1990-2017: a systematic analysis for the Global Burden of Disease Study 2017. The Lancet, 392(10159), 1789-1858. https://doi.org/10.1016/S0140-6736(18)32279-7

Tan, H., Qin, L., Jiang, Z., Wu, Y., \& Ran, B. (2018). A hybrid deep learning based traffic flow prediction method and its understanding. Transportation Research Part C: Emerging Technologies, 90(January), 166-180. https://doi.org/10.1016/j.trc.2018.03.001

Taylor, K., Post, A., Hoshizaki, T. B., \& Gilchrist, M. D. (2019). The effect of a novel impact management strategy on maximum principal strain for reconstructions of American football concussive events. Proceedings of the Institution of Mechanical Engineers, Part P: Journal of Sports Engineering and Technology, 233(4), 503-513. https://doi.org/10.1177/1754337119857434 